\title{
Molecular characterization and genetic relationships of seven piranha species of the genera Serrasalmus and Pygocentrus (Characiformes: Serrasalmidae) from Paraná-Paraguay, São Francisco and Tocantins River basins in Brazil
}

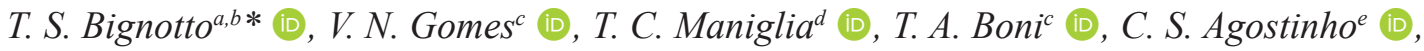 \\ S. M. A. P. Priolic iD and A. J. Prioli ${ }^{c}$ \\ ${ }^{a}$ Grupo de Pesquisas em Recursos Pesqueiros e Limnologia - GERPEL, Universidade Estadual do Oeste do Paraná - \\ UNIOESTE, Campus de Toledo, Rua da Faculdade, 645, CEP 85903-000, Toledo, PR, Brasil \\ 'Programa de Pós-graduação em Genética e Melhoramento, Universidade Estadual de Maringá - UEM, Av. Colombo, \\ 5790, CEP 87020-900, Maringá, PR, Brasil \\ 'Núcleo de Pesquisas em Limnologia, Ictiologia e Aquicultura - NUPÉLIA, Universidade Estadual de Maringá - UEM, \\ Av. Colombo, 5790, CEP 87020-900, Maringá, PR, Brasil \\ dUniversidade Tecnológica Federal do Paraná - UTFPR, Campus de Toledo, Rua Cristo Rei, 19, CEP 85902-490, \\ Toledo, PR, Brasil

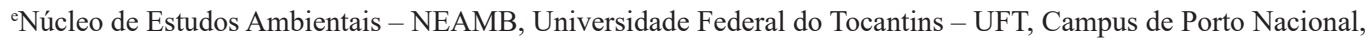 \\ Rua Três, s/n, CEP 77500-000, Porto Nacional, TO, Brasil \\ *e-mail: thais.bignotto@unioeste.br
}

Received: January 24, 2019 - Accepted: August 9, 2019 - Distributed: November 30, 2020

(With 3 figures)

\begin{abstract}
Genetic and phylogenetic relationships among seven piranha species of the genera Serrasalmus and Pygocentrus from the Paraná-Paraguay, São Francisco and Tocantins River basins were evaluated in the present study by partial sequences of two mitochondrial genes, Cytochrome b and Cytochrome c Oxidase I. Phylogenetic analysis of Maximum-Likelihood and Bayesian inference were performed. Results indicated, in general, greater genetic similarity between the two species of Pygocentrus (P. nattereri and P. piraya), between Serrasalmus rhombeus and S. marginatus and between S. maculatus, S. brandtii and S. eigenmanni. Pygocentrus nattereri, S. rhombeus and S. maculatus showed high intraspecific genetic variability. These species have each one, at least two different mitochondrial lineages that, currently, occur in sympatry (S. rhombeus) or in allopatry (P. nattereri and S. maculatus). Species delimitation analysis and the high values of genetic distances observed between populations of $S$. rhombeus and of $S$. maculatus indicated that each species may corresponds to a complex of cryptic species. The non-monophyletic condition of $S$. rhombeus and $S$. maculatus reinforces the hypothesis. The geographic distribution and the genetic differentiation pattern observed for the piranha species analyzed herein are discussed regarding the geological and hydrological events that occurred in the hydrographic basins.
\end{abstract}

Keywords: mitochondrial DNA, Cytochrome b, Cytochrome c Oxidase subunit I, phylogeny, species complex.

\section{Caracterização molecular e relações genéticas de sete espécies de piranhas dos gêneros Serrasalmus e Pygocentrus (Characiformes: Serrasalmidae) das bacias hidrográficas Paraná-Paraguai, São Francisco e Tocantins, no Brasil}

\section{Resumo}

Relações genéticas e filogenéticas de sete espécies de piranhas dos gêneros Serrasalmus e Pygocentrus das bacias hidrográficas Paraná-Paraguai, São Francisco e Tocantins foram avaliadas com base em sequências parciais dos genes mitocondriais Citocromo b e Citocromo c Oxidase I. Foram realizadas análises filogenéticas de Máxima Verossimilhança e de inferência Bayesiana. Os resultados indicaram, em geral, maior similaridade genética entre as duas espécies de Pygocentrus (P. nattereri e P. piraya), entre Serrasalmus rhombeus e $S$. marginatus e entre $S$. maculatus, $S$. brandtii e $S$. eigenmanni. Pygocentrus nattereri, $S$. rhombeus e $S$. maculatus revelaram ter alta variabilidade genética intraespecífica. Essas espécies têm, cada uma, pelo menos duas linhagens mitocondriais que, atualmente, ocorrem em simpatria (S. rhombeus) ou alopatria (P. nattereri e $S$. maculatus). Análises de delimitação de espécies e os altos valores de distância genética observados entre as populações de $S$. rhombeus e de $S$. maculatus indicam que cada espécie 
pode, na verdade, corresponder a um complexo de espécies crípticas. A condição não-monofilética de $S$. rhombeus e S. maculatus reforça essa hipótese. A distribuição geográfica e o padrão de diferenciação genética observados para as espécies de piranhas analisadas são discutidos com relação aos eventos geológicos e hidrológicos que ocorreram nas bacias hidrográficas.

Palavras-chave: DNA mitocondrial, Citocromo b, Citocromo c Oxidase subunidade I, filogenia, complexo de espécies.

\section{Introduction}

Piranhas and closely related genera of pacus and tambaquis comprise the family Serrasalmidae (Ostariophysi: Characiformes), currently with 98 valid species in 16 genera (Fricke et al., 2019). The largest group of Serrasalmidae is comprised by the piranhas. Jégu (2003) estimated the number of piranhas at 38 recognized species. According to Freeman et al. (2007), "piranhas" or the "true piranhas" are a group of fishes that traditionally includes the genera Serrasalmus (24, perhaps 28 species), Pristobrycon (5), Pygocentrus (3 or 4) and Pygopristis (1). However, some authors also include the scale-eating genus Catoprion and the plant-eating genus Metynnis in the same group (e.g., Ortí et al., 1996; Nakayama et al., 2002).

Piranhas are freshwater Neotropical fish endemic from South America, occurring in the rivers of the Amazon, Orinoco, Guiana, Araguaia-Tocantins, Paraná-Paraguay and São Francisco basins (Jégu, 2003). Despite their ecological and economic importance, the taxonomy and systematic classification of piranhas and other serrasalmids are confusing. As a result, species identification and phylogenetic placement of many taxa are problematic (Freeman et al., 2007; Thompson et al., 2014).

Evolutionary relationships among species of piranhas have been the subject of several publications with morphological (Machado-Allison, 1983), cytological (Nakayama et al., 2002, 2012), parasitological (Van Every and Kritsky, 1992) and molecular markers (Ortí et al., 1996, 2008; Freeman et al., 2007; Hubert et al., 2007; Thompson et al., 2014; Machado et al., 2018; Mateussi et al., 2019). Morphological and molecular approaches agree with the hypothesis that the genera of piranhas Pygopristis, Pygocentrus, Pristobrycon and Serrasalmus together with Catoprion, represent a monophyletic unit of the family Serrasalmidae. However, relationships within the group are not yet well established and at least Serrasalmus and Pristobrycon may be non-monophyletic (Ortí et al., 1996, 2008; Freeman et al., 2007; Thompson et al., 2014).

Genetic characterization of piranha species is therefore essential to aid in the elucidation of genetic relationships and identification at species level. Hence, the goal of our research was to use partial sequences of the mitochondrial genes Cytochrome b (cytb) and Cytochrome c Oxidase subunit I ( $\mathrm{col})$ to characterize and to elucidate the genetic and phylogenetic relationships of seven piranha species of the genera Serrasalmus (S. maculatus Kner, 1858; S. marginatus Valenciennes, 1837; S. eigenmanni Norman, 1929; S. rhombeus Linnaeus, 1766 and S. brandtii Lütken, 1875) and Pygocentrus (P. nattereri Kner, 1858 and P. piraya Cuvier, 1819) from the Upper Paraná, Upper Paraguay, São Francisco and Tocantins River basins, in Brazil.

\section{Material and Methods}

\subsection{Sample collection}

Sixty-four piranha specimens of the genera Serrasalmus and Pygocentrus were collected at four hydrographic basins: Upper Paraná, Upper Paraguay, Tocantins and São Francisco Rivers (Figure 1; Table 1). Specimens were anaesthetized and subsequently sacrificed by overdosing of clove oil. Muscle samples were preserved in 96\% ethanol and maintained at $-20^{\circ} \mathrm{C}$ before DNA extraction. Piaractus brachypomus was used as outgroup in phylogenetic analysis (GenBank accession numbers: AY791429 for $c y t b$ and FJ978042 for coI sequences).

\subsection{DNA isolation, PCR amplification and sequencing}

Genomic DNA was isolated from muscle tissues using the phenol-chloroform protocol (Green and Sambrook, 2012). After DNA quantification, mitochondrial DNA fragments were amplified by Polymerase Chain Reaction

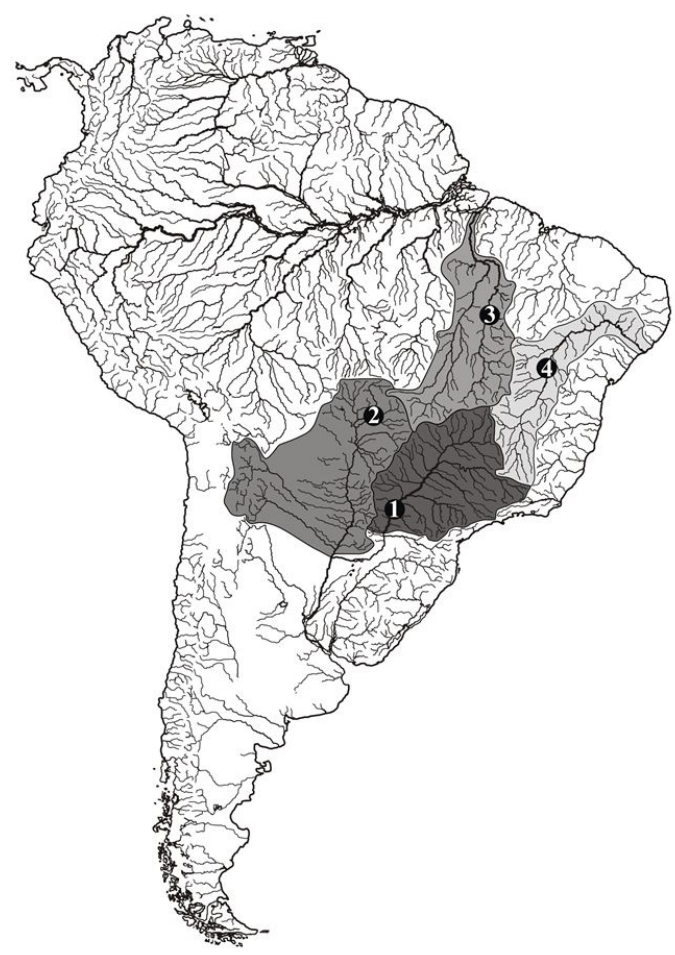

Figure 1. Sample collection sites of the piranha genera Serrasalmus and Pygocentrus in Brazil. Numbers correspond to the local sample of the respective river basin: (1) Upper Paraná River; (2) Upper Paraguay River; (3) Tocantins River; and (4) São Francisco River. 
Table 1. Piranha species of the genera Serrasalmus and Pygocentrus analyzed in the present study.

\begin{tabular}{|c|c|c|c|c|c|c|c|}
\hline \multirow{2}{*}{ Species } & \multirow{2}{*}{ Sampling sites } & \multirow{2}{*}{ Code } & \multirow{2}{*}{$\mathbf{N}$} & \multirow{2}{*}{ Voucher } & \multirow{2}{*}{$\begin{array}{c}\text { Collection } \\
\text { date }\end{array}$} & \multicolumn{2}{|c|}{ GenBank accession no. } \\
\hline & & & & & & cytb & coI \\
\hline S. maculatus & $\begin{array}{l}\text { Upper Paraguay } \\
\text { basin (Manso River) }\end{array}$ & PY & 7 & NUP 884 & Jul., 2006 & KP256436-442 & KP256372-378 \\
\hline S. maculatus & $\begin{array}{l}\text { Upper Paraná basin } \\
\text { (Garças Lagoon) }\end{array}$ & PR & 3 & NUP 4208 & Feb., 2006 & KP256443-445 & KP256379-381 \\
\hline S. maculatus & $\begin{array}{l}\text { Upper Paraná basin } \\
\text { (Baía River) }\end{array}$ & PR & 4 & NUP 4208 & $\begin{array}{l}\text { Feb. \& Nov., } \\
2006\end{array}$ & KР256446-449 & KP256382-385 \\
\hline S. maculatus & $\begin{array}{l}\text { Upper Paraná basin } \\
\text { (Floodplain) }\end{array}$ & PR & 5 & NUP 4208 & $\begin{array}{l}\text { Feb. \& Nov., } \\
2006\end{array}$ & KP256450-454 & KP256386-390 \\
\hline S. maculatus & Tocantins River & TO & 7 & UNT 8175 & May, 2007 & KP256455-461 & KP256391-397 \\
\hline S. marginatus & $\begin{array}{l}\text { Upper Paraguay } \\
\text { basin (Manso River) }\end{array}$ & PY & 4 & NUP 885 & Jul., 2006 & KP256462-465 & KP256398-401 \\
\hline S. marginatus & $\begin{array}{l}\text { Upper Paraná basin } \\
\text { (Garças Lagoon) }\end{array}$ & PR & 2 & NUP 6374 & Feb., 2006 & KP256466-467 & KP256402-403 \\
\hline S. marginatus & $\begin{array}{l}\text { Upper Paraná basin } \\
\text { (Floodplain) }\end{array}$ & PR & 5 & NUP 6374 & $\begin{array}{l}\text { Feb. \& Nov., } \\
2006\end{array}$ & KP256468-472 & KP256404-408 \\
\hline S. rhombeus & Tocantins River & TO & 6 & - & $\begin{array}{l}\text { Oct. \& Nov., } \\
2005\end{array}$ & KP256473-478 & KP256409-414 \\
\hline S. eigenmanni & Tocantins River & TO & 5 & - & Dec., 2005 & KP256479-483 & KР256415-419 \\
\hline S. brandtii & São Francisco River & $\mathrm{SF}$ & 4 & - & Oct., 2009 & KP256484-487 & KP256420-423 \\
\hline P. nattereri & $\begin{array}{l}\text { Upper Paraguay } \\
\text { basin (Manso River) }\end{array}$ & PY & 4 & NUP 886 & Jul., 2006 & KP256488-491 & KP256424-427 \\
\hline P. nattereri & Tocantins River & TO & 4 & UNT 8148 & Mar., 2006 & KP256492-495 & KP256428-431 \\
\hline P. piraya & São Francisco River & SF & 4 & - & Oct., 2009 & KP256496-499 & KP256432-435 \\
\hline
\end{tabular}

Code = sample site abbreviation; $\mathrm{N}=$ number of analyzed specimens; Voucher: NUP = number of catalogue at Ichthyological Collection of the Nupelia (Núcleo de Pesquisas em Limnologia, Ictiologia e Aquicultura)/Universidade Estadual de Maringá; $\mathrm{UNT}=$ number of catalogue at Laboratory of Ichthyology and Systematic of Universidade Federal do Tocantins.

(PCR), using aliquots of total DNA. Cytb region was amplified with the primers H16498 (5'-CCT GAA GTA GGA ACC AGA TG-3'; Meyer et al., 1990) and L14841 (5'-CCA TCC AAC ATC TCA GCA TGA TGA AA-3'; Kocher et al., 1989), whereas coI gene was PCR amplified using the primers H7152 (5'-CAC CTC AGG GTG TCC GAA RAA YCA RAA-3'; Ivanova et al., 2007) and L6448-F1 (5'-TCA ACC AAC CAC AAA GAC ATT GGC AC-3'; Ward et al., 2005). Reactions were performed in a total volume of $25 \mu \mathrm{L}$ containing Tris-KCl buffer $(20 \mathrm{mM}$ Tris- $\mathrm{HCl} \mathrm{pH} 8.4$ and $50 \mathrm{mM} \mathrm{KCl}), 1.5 \mathrm{mM} \mathrm{MgCl}_{2}, 2.5 \mu \mathrm{M}$ of each primer, $0.1 \mathrm{mM}$ of each dNTP, 2.5 units of DNA Taq polymerase, $30 \mathrm{ng}$ of genomic DNA and deionized and autoclaved water. PCR profile in thermal cycler included an initial pre-melt of 4 min at $94^{\circ} \mathrm{C}$, followed by 40 cycles of $15 \mathrm{~s}$ denaturation at $94^{\circ} \mathrm{C}, 30 \mathrm{~s}$ of annealing at $59-61{ }^{\circ} \mathrm{C}$ (for cytb) or $52-55^{\circ} \mathrm{C}$ (for $c o I$ ) and $2 \mathrm{~min}$ extension at $72^{\circ} \mathrm{C}$, ending with a $10 \mathrm{~min}$ extension at $72{ }^{\circ} \mathrm{C}$.

The amplification efficiency was confirmed on $1 \%$ agarose gel. Samples were then purified with polyethylene glycol. Resulting fragments were once more amplified with primers L14841 or L6448-F1 for cytb or coI regions, respectively. Approximately $50 \mathrm{ng}$ of the final products were directly used in the nucleotide sequencing reactions using the DYEnamic ET Dye Terminator Kit (Amersham Biosciences) in the automatic sequencer MegaBACE 1000 (Amersham Biosciences), following manufacturer instructions.

\subsection{Sequence and phylogenetic analysis}

Partial nucleotide sequences of $c y t b$ and $c o I$ were edited and aligned separately by Clustal Omega (Sievers et al., 2011) and BioEdit 7.0.1 (Hall, 2011) and, when necessary, adjusted manually. Genetic diversity indices such as polymorphic sites, number of transitions and transversions, $p$-distances and nucleotide compositions were obtained with MEGA7 (Kumar et al., 2016).

After checking for congruency among tree topologies derived from the single-gene phylogenies, analyses of Maximum-Likelihood (ML) and Bayesian (BA) inferences were based on the concatenated sequences of $c y t b$ and $c o I$. The best-fit model of nucleotide evolution was estimated by PartitionFinder 2.1 software (Lanfear et al., 2012). Best-scoring ML trees were estimated with the raxmlGUI software (Silvestro and Michalak, 2012), using rapid bootstrap algorithm, autoMRE function for resamplings, and the partition set defined by the PartitionFinder 2.1. BA trees were calculated using the uncorrelated lognormal relaxed-clock model implemented in BEAST 1.8.2 with an input file generated in BEAUti 1.8.0 (Drummond et al., 2012). The Yule process of speciation, which assumes a constant speciation rate among lineages, was applied as a tree prior. A Monte-Carlo Markov chain (MCMC) of $50,000,000$ generations was performed and sampled every 1,000 generations. Results were checked using Tracer 1.6 
(Rambaut et al., 2014; ESS $>200$ ). The final trees were calculated after $20 \%$ of burn-in. Tree was edited with FigTree (Rambaut, 2010). Support for nodes was determined using posterior probabilities (PP; calculated by BEAST).

\subsection{Species delimitation analyses}

Three species delimitation methods were applied to the $c o I$ sequences only using either sequence-based estimations (Automatic Barcode Gap Discovery - ABGD) or topology-based analyses based on the ML or BA inferences (Poisson Tree Process - PTP, and General Mixed Yule Coalescent Model - GMYC). The ABGD method was conducted on the online server (Puillandre et al., 2012) using the default parameters and the Kimura model $(\mathrm{K} 80 ; 2.0)$ of nucleotide substitution. The PTP model was implemented on the online server (Zhang et al., 2013) using the best-scoring ML tree constructed on raxmlGUI, as mentioned before. The GMYC method was implemented using the ultrametric tree based on the Bayesian inference constructed in BEAST, as mentioned above. Tracer 1.6 software was used to check for chain convergence and the effective sampling size (ESS $>200$ ). The identification of significant clusters was implemented in Rstudio software (RStudio Team, 2016) by using the splits package (Ezard et al., 2009).

\section{Results}

The total length of the concatenated sequences of partial $c o I$ (549 bp) and cytb (592 bp) genes was of 1,141 bp long, without indels. A total of 167 variable sites were identified within the 64 analyzed specimens (excluding outgroup); 157 of them were parsimony-informative. Polymorphic sites and diagnostic nucleotides are presented in Supplementary Material 1. Sequence analysis revealed a ratio of transitions and transversions of $\mathrm{R}=\mathrm{si} / \mathrm{sv}=8.26$ and a proportion of bases of $\mathrm{T}=26.7 \%, \mathrm{C}=32.5 \%, \mathrm{~A}=24.1 \%$ and $\mathrm{G}=16.7 \%$.

Concatenated $c y t b$ and $c o I$ sequences were efficient in discriminating the piranha species, revealing high bootstrap or posterior probabilities values supporting clades in both dendrograms (Figure 2) as well as consistent $p$-distance
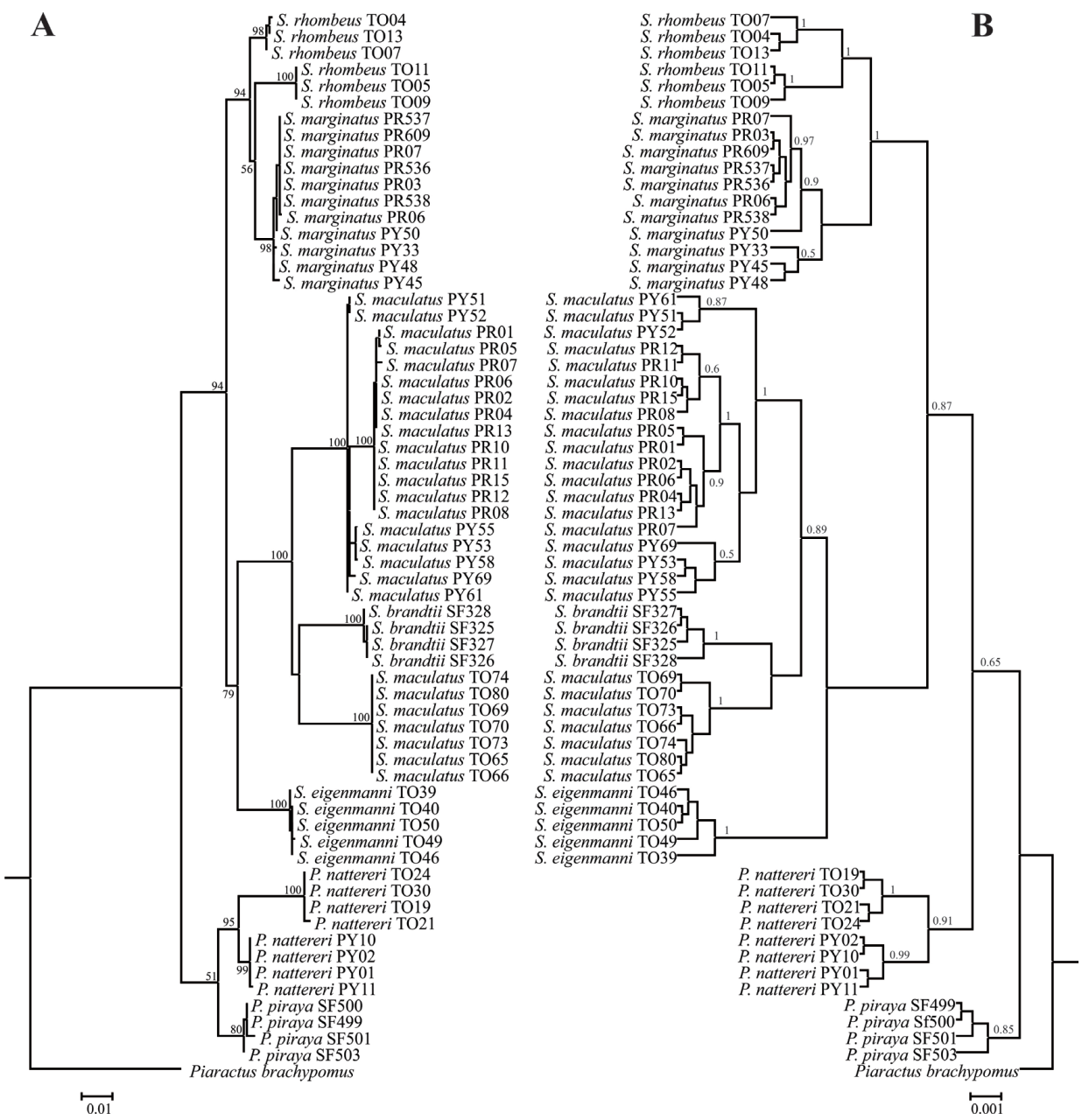

Figure 2. Maximum-likelihood (ML; A) and Bayesian (BA; B) phylogenetic trees inferred from the concatenated sequences of Cytochrome b and Cytochrome c oxidase I mitochondrial genes of Serrasalmus and Pygocentrus species. Values near branches indicate bootstrap and posterior probabilities support values for nodes in the ML and BA analysis, respectively. 
values (Table 2). Single-gene topologies obtained with $c y t b$ or $c o I$ sequences were similar with each other (data not shown) and with the topology based on the concatenated sequences. Only two taxa were problematic regarding their positions in the trees: S. eigenmanni and
S. brandtii. In the ML dendrogram obtained with coI sequences only, S. eigenmanni was the sister group of $S$. rhombeus and S. marginatus (see Figure 3), instead of S. maculatus and S. brandtii (as in Figure 2). Serrasalmus brandtii, on the other hand, was closer to S. maculatus

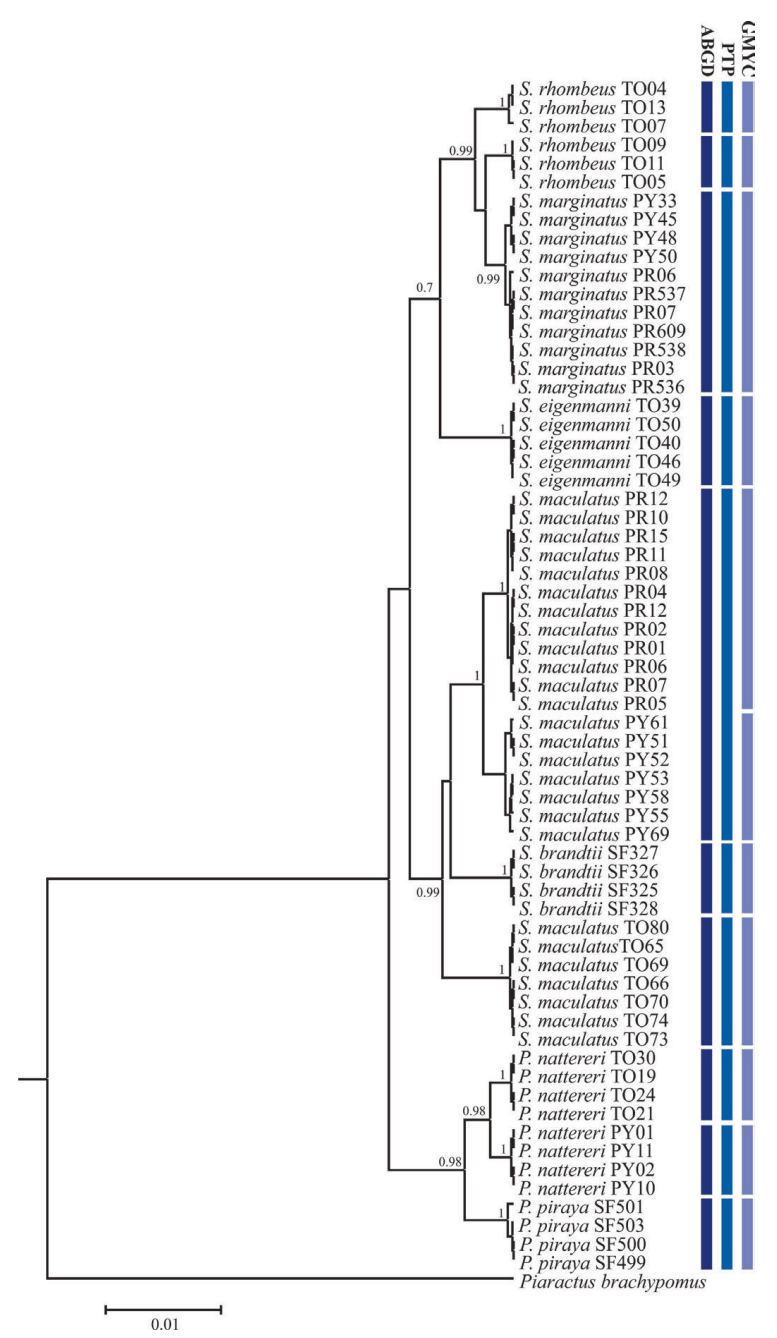

Figure 3. Species delimitation analyses based on the Cytochrome c Oxidase I sequences of Serrasalmus and Pygocentrus species from Upper Paraná (PR), Upper Paraguay (PY), São Francisco (SF) and Tocantins (TO) River basins, using Automatic Barcode Gap Discovery (ABGD), Poisson Tree Processes (PTP), and General Mixed Yule Coalescent (GMYC) methods. Bayesian (posterior probability) support values for each node are presented in the Bayesian tree.

Table 2. Mean $p$-distance values (\%) between species of the piranha genera Serrasalmus and Pygocentrus, based on the concatenated sequences of the mitochondrial DNA genes Cytochrome b and Cytochrome c Oxidase I.

\begin{tabular}{|c|c|c|c|c|c|c|c|}
\hline Species & 1 & 2 & 3 & 4 & 5 & 6 & 7 \\
\hline \multicolumn{8}{|l|}{ 1. S. maculatus PY and PR } \\
\hline 2. S. maculatus $\mathrm{TO}$ & 4.01 & & & & & & \\
\hline 3. S. marginatus $\mathrm{PY}$ and $\mathrm{PR}$ & 4.73 & 4.43 & & & & & \\
\hline 4. S. rhombeus TO & 4.69 & 4.41 & 1.68 & & & & \\
\hline 5. S. eigenmanni TO & 4.64 & 4.41 & 3.02 & 3.55 & & & \\
\hline 6. S. brandtii $\mathrm{SF}$ & 3.63 & 3.74 & 4.67 & 4.75 & 4.22 & & \\
\hline 7. $P$. nattereri $\mathrm{PY}$ and $\mathrm{TO}$ & 5.74 & 5.97 & 4.60 & 4.59 & 4.60 & 5.72 & \\
\hline 8. P. piraya $\mathrm{SF}$ & 5.71 & 5.78 & 4.16 & 4.25 & 4.33 & 5.85 & 2.48 \\
\hline
\end{tabular}

PY = Upper Paraguay River basin; PR = Upper Paraná River basin; TO = Tocantins River; SF = São Francisco River. 
from Paraná-Paraguay basin (data not shown), rather than $S$. maculatus from Tocantins, in the ML tree based on cytb sequences. All the analyzed species of Serrasalmus were grouped in a monophyletic clade in the ML and BA trees. The same was observed for Pygocentrus in the ML analysis (Figures 2 and 3 ).

The two species of the genus Pygocentrus formed a basal clade in both dendrograms, and the relationships among specimens were mostly corroborated in the ML and BA analyses. Pygocentrus nattereri and $P$. piraya constituted each one a monophyletic group and they presented a genetic distance from each other of $2.48 \%$ (Table 2). In addition, P. nattereri was separated in two clades, each one corresponding to the populations of Tocantins and Upper Paraguay River basins. This fact was corroborated by the values of genetic distance: although variability within each group was low $(0.04 \%$ to $0.08 \%)$, the genetic distance between the two populations of $P$. nattereri was of $2.25 \%$ (Table 3 ).

The clade constituted by Pygocentrus was the sister group of all species of the genus Serrasalmus in dendrograms. As observed for P. nattereri, genetic isolation of populations from Tocantins River and Paraná-Paraguay hydrographic basin was also observed for S. maculatus. Specimens of $S$. maculatus from the Paraná-Paraguay River basin formed a clade distinct from the population of Tocantins River (Figure 2) and showed high genetic distance values (4.01\%; Table 2). However, no significant differentiation was observed between $S$. maculatus of Paraná and Paraguay Rivers basins. These results were corroborated by the genetic distance values (Table 3 ). The population of $S$. maculatus from Tocantins River diverged from the populations of Paraná and Paraguay basins by mean values of $4.20 \%$ and $3.69 \%$, respectively. On the other hand, the genetic differentiation between S. maculatus from Paraná and Paraguay Rivers was only $1.04 \%$. In addition, $S$. brandtii was placed within the clade formed by $S$. maculatus (Figure 2), indicating the non-monophyletic condition of $S$. maculatus. Serrasalmus eigenmanni was defined as the sister group of the clade formed by $S$. maculatus and S. brandtii.

Serrasalmus rhombeus and $S$. marginatus were genetically close to each other and formed a major clade that was further divided into three sub-clades: one formed exclusively by $S$. marginatus and two formed by $S$. rhombeus (Figure 2). The two clades of $S$. rhombeus were distant from each other by a value of genetic $p$-distance of $1.78 \%$ (Table 3). Values of such magnitude were also identified between $S$. rhombeus and S. marginatus ( $p$-distance $=1.68 \%$; Table 2). Additionally, S. rhombeus was non-monophyletic in the ML (Figure 2A) and BA (Figure 3) trees.

The three species delimitation analyses were mostly congruent and returned ten (for ABGD and PTP methods) or eleven (GMYC) lineages for Serrasalmus and Pygocentrus species (Figure 3). All methods split both P. nattereri and $S$. rhombeus into two subgroups. However, S. maculatus was divided into two (ABGD and PTP) or three (GMYC) lineages, depending on the approach.

\section{Discussion}

\subsection{Delimitation of piranha species}

All of the piranha species analyzed herein were discriminated based on the $c y t b$ and $c o I$ mitochondrial DNA (mtDNA) sequences and based on the species delimitation analyses (ABGD, PTP and GMYC). Genetic $p$-distance mean values between species varied from $1.68 \%$ to $5.97 \%$ (Table 2). The genetic differentiation between $P$. nattereri and $P$. piraya was evident. Although the value of $p$-distance detected between the species were low $(2.48 \%)$, this is an expected result, since the speciation event leading to $P$. nattereri and $P$. piraya occurred recently, during the last 2.6 $\pm 0.2 \mathrm{Ma}$ (Mateussi et al., 2019).

Table 3. Mean $p$-distance values (\%) within (diagonal) and between (below the diagonal) populations of the piranha genera Serrasalmus and Pygocentrus, based on the concatenated sequences of the mitochondrial genes Cytochrome b and Cytochrome c Oxidase I.

\begin{tabular}{|c|c|c|c|c|c|c|c|c|c|c|c|c|}
\hline $\begin{array}{c}\text { Species/ } \\
\text { Population }\end{array}$ & 1 & 2 & 3 & 4 & 5 & 6 & 7 & 8 & 9 & 10 & 11 & 12 \\
\hline 1. S. maculatus PY & 0.29 & & & & & & & & & & & \\
\hline 2. S. maculatus PR & 1.04 & 0.11 & & & & & & & & & & \\
\hline 3. S. maculatus TO & 3.69 & 4.20 & 0.00 & & & & & & & & & \\
\hline 4. S. marginatus $\mathrm{PY}$ & 4.41 & 4.77 & 4.33 & 0.17 & & & & & & & & \\
\hline 5. S. marginatus $\mathrm{PR}$ & 4.55 & 4.92 & 4.48 & 0.23 & 0.02 & & & & & & & \\
\hline 6. S. rhombeus TO 1 & 3.95 & 4.29 & 4.09 & 1.40 & 1.50 & 0.01 & & & & & & \\
\hline 7. S. rhombeus TO 2 & 4.98 & 5.34 & 4.73 & 1.84 & 1.94 & 1.78 & 0.00 & & & & & \\
\hline 8. S. eigenmanni TO & 4.43 & 4.76 & 4.41 & 2.93 & 3.08 & 3.15 & 3.94 & 0.07 & & & & \\
\hline 9. S. brandtii SF & 3.44 & 3.74 & 3.74 & 4.58 & 4.72 & 4.44 & 5.06 & 4.22 & 0.04 & & & \\
\hline 10. P. nattereri $\mathrm{PY}$ & 5.19 & 5.32 & 5.67 & 4.14 & 4.27 & 3.87 & 4.40 & 4.22 & 5.47 & 0.04 & & \\
\hline 11. $P$. nattereri $\mathrm{TO}$ & 6.14 & 6.26 & 6.26 & 4.90 & 5.04 & 4.77 & 5.30 & 4.98 & 5.98 & 2.25 & 0.08 & \\
\hline 12. $P$. piraya $\mathrm{SF}$ & 5.65 & 5.74 & 5.78 & 4.07 & 4.20 & 3.94 & 4.55 & 4.33 & 5.85 & 1.77 & 3.20 & 0.17 \\
\hline
\end{tabular}

PY = Upper Paraguay River basin; PR = Upper Paraná River basin; TO = Tocantins River; SF = São Francisco River. 
We also detected high genetic variability within P. nattereri, as previously reported by Mateussi et al. (2019) and Luz et al. (2015). Specimens of $P$. nattereri were separate in the dendrograms according to the sample locality. Values of $p$-distance observed between populations of $P$. natterer $i$ (Paraguay and Tocantins River basins; 2.25\%; Table 3) were lower than the values identified between species of Serrasalmus, suggesting that the existing polymorphism in $P$. nattereri is related to intra-specific variability, which is commonly observed in geographically isolated populations. Distinction between populations of $P$. nattereri of different river basins has already been discussed (Fink, 1993; Fink and Zelditch, 1997), appointing to shape differences consistent with the geographical variation of a widely distributed species (Fink and Zelditch, 1997). However, all species delimitation analysis recovered two mtDNA lineages among P. nattereri specimens (Figure 3). Similarly, Mateussi et al. (2019) detected at least five lineages of $P$. nattereri in five hydrographic river basins (Amazonas, Guaporé, Itapecuru, Paraná-Paraguay and Tocantins-Araguaia). The authors also concluded that these lineages can be potentially sibling species, a special case of cryptic species, representing the P. nattereri species complex (Mateussi et al., 2019). Finally, the monophyletic condition of $P$. nattereri confirmed in the studies of Fink (1993) and Ortí et al. (1996) was also observed in our analysis (Figure 2).

The same pattern of genetic differentiation identified in $P$. nattereri was also observed for the specimens of $S$. maculatus, i.e., population of $S$. maculatus from Tocantins River basin was segregated from the populations of Paraná-Paraguay system. In the case of S. maculatus, $p$-distance values were relatively higher than in $P$. nattereri. ABGD, PTP and GMYC approaches split $S$. maculatus in two or three distinct lineages, as previously described by Bignotto et al. (2019). The high values of genetic distance and the differentiation of $S$. maculatus haplogroups from Tocantins and Paraná-Paraguay River basins, associated with the non-monophyletic condition of $S$. maculatus observed in the dendrograms, may constitute evidence for more than one species within S. maculatus (Bignotto et al., 2019). Similarly, Machado et al. (2018) did not recover the monophyletic condition of the species.

In addition to the wide geographic distribution, S. maculatus has high karyotypic variability (Cestari and Galetti Junior, 1992; Nakayama et al., 2000; Centofante et al., 2002; Nakayama et al., 2002). The different cytotypes identified in $S$. maculatus are related to the different hydrographic basins, characterizing differences among populations. Consequently, these evidences support a complex of cryptic species for $S$. maculatus (Nakayama et al., 2000).

Results obtained in the present study also revealed the close relationship between $S$. maculatus and $S$. brandtii ( $p$-distance ranging from $3.63 \%$ to $3.74 \%$; Table 2 ), corroborating previous studies (Cestari and Galetti Junior, 1992; Hubert et al., 2007). Cestari and Galetti Jr. (1992b) reported that $S$. brandtii of the São Francisco River and S. maculatus from the Upper Paraná River have similar karyotypes. According to Hubert et al. (2007), the event that gave rise to $S$. brandtii and S. maculatus occurred around $8 \mathrm{Ma}$.

The low genetic $p$-distance values observed between S. rhombeus and S. marginatus (1.68\%; Table 2) were inferior to those detected among other species of piranhas analyzed in the present study. Values of such magnitude could be explained by two hypotheses. First, specimens namely $S$. rhombeus and $S$. marginatus might represent only one species with wide intraspecific variability. Another more reasonable explanation is that $S$. rhombeus and $S$. marginatus have undergone a recent speciation process, which impeded the accumulation of mtDNA polymorphisms. Both $S$. rhombeus and S. marginatus have been previously described, are well-defined species, and are morphologically distinct from each other (Jégu, 2003), which gives support for the second hypothesis.

Analysis clearly divided specimens of $S$. rhombeus from Tocantins River basin into two clades. Furthermore, $p$-distance values detected between these two groups of $S$. rhombeus are in the same magnitude of interspecific genetic divergence observed between $S$. rhombeus and $S$. marginatus. Additionally, ML and BA trees revealed the non-monophyletic condition of $S$. rhombeus. Thompson et al. (2014) and Machado et al. (2018) also did not obtain the monophyly of $S$. rhombeus. Hence, in the present study, we found evidence for at least two sympatric mitochondrial lineages of $S$. rhombeus that occur in the Tocantins River basin which diverged recently from each other. We suggest additional studies combining molecular and morphological data to confirm if both groups of $S$. rhombeus should be considered different species.

Cytogenetic studies also reported the high variability within S. rhombeus (Nakayama et al., 2001, 2012). Different $S$. rhombeus cytotypes were found in both allopatry and sympatry, suggesting that each cytotype represents a different fish species (Nakayama et al., 2001). Nakayama et al. (2001) also noted that differences in parasite species supported the recognition of a cryptic species of piranha within $S$. rhombeus. Our results agree with previously described data: according to Géry (1976), S. rhombeus is a species complex (rhombeus group) comprising six to nine species (Nakayama et al., 2001). Consequently, caution should be used in any decision regarding the species complex of the rhombeus group.

Therefore, mtDNA sequences ( $c y t b$ and $c o l$ ) were sufficient to characterize and discriminate all of the piranha species analyzed herein from the Upper Paraná, Upper Paraguay, São Francisco and Tocantins River basins, with additional evidence for the possible occurrence of cryptic species in S. maculatus, S. rhombeus and P. nattereri.

\subsection{Relationships among hydrographic basins}

The mitochondrial haplotypes of both $P$. nattereri and $S$. maculatus populations were related to the Amazon (Tocantins) or Paraná-Paraguay hydrographic basins, i.e., the genetic diversity is geographically structured and there are no shared haplotypes among rivers. The biogeographical pattern and the genetic differentiation found in the 
populations of both species can be explained by vicariance and/or dispersion events.

According to Hubert and Renno (2006), the Paraná-Paraguay system split from the Amazon at $10 \mathrm{Ma}$, in the Late Miocene. Therefore, during the formation of these basins, the definitive separation of the two populations of both $S$. maculatus and $P$. nattereri was possible due to vicariance. Similarly, dispersal events between different drainages were hypothesized to promote post-dispersal allopatric speciation once the connections ceased (Hubert et al., 2007). During the last $10 \mathrm{Ma}$, headwater-capture events occurred between the Amazon and the Paraná systems (Lundberg et al., 1998). Several studies have reported the possible connection between the Amazon and the Paraná-Paraguay systems (e.g., Aquino and Schaefer, 2010). Therefore, vicariance and dispersion events could be related to the genetic differentiation of the populations of both S. maculatus and P. nattereri of the Amazon and the Paraná-Paraguay River basins.

The biogeography associated to the distribution of the haplotypes of both species (S. maculatus and P. nattereri) indicate that the populations are isolated geographically, reproductively and/or by distance for enough time so that mutations could be accumulated in the mtDNA molecule. Hubert et al. (2007) suggested that at least $P$. nattereri colonized the Paraná River at $2 \mathrm{Ma}$, which justifies the low genetic divergence identified in the populations of $P$. nattereri. However, the differentiation between the populations of $S$. maculatus must have occurred earlier, due to the higher genetic divergence detected for this species.

Fishes from the same river basin tend to be most closely related, whereas populations of fishes from adjacent localities within basins should be most similar (Lovejoy and Araújo, 2000). Such genetic pattern was identified for both $S$. maculatus and $S$. marginatus, species that occur in the Paraná-Paraguay hydrographic basin. Within the Upper Paraná River or the Upper Paraguay River, populations of both $S$. maculatus and $S$. marginatus revealed minor values of genetic distance. However, comparisons of populations between these localities showed only slightly higher values of genetic distance, characterizing polymorphisms within a species.

Probably, gene flow between populations of the Paraná-Paraguay hydrographic basin of S. marginatus and also of populations of $S$. maculatus has occurred until recently or may still occur. Occasional migrations from upstream to downstream and/or incorporation of the subpopulation from the Itaipu region to the population of the Upper Paraná River may have contributed to the attenuation of the genetic differentiation between these populations. The Guaíra Falls (Seven Falls) has characterized an efficient geographical barrier against the migration from downstream to upstream (Júlio Júnior et al., 2009). However, migration from upstream to downstream could frequently happen.

Genetic similarity was higher between the piranha species from the São Francisco River (S. brandtii and $P$. piraya) and the Paraná-Paraguay hydrographic basin
(S. maculatus and P. nattereri) than with species occurring in the Tocantins River ( $S$. maculatus and $P$. nattereri) (Table 3 ). This could be explained by the hydrological and geological history. Events of headwater capture were identified after the separations of the Upper Paraná and the São Francisco River basins (Hubert and Renno, 2006), which could enable ichthyofauna exchange between these two hydrographic basins. However, until now, headwater capture events have not been identified between São Francisco and Tocantins River basins.

Another two situations arose in the region and promoted fish dispersion between hydrographic basins. First, in the 1960s, the artificial transposition of the Piumhi River, originally from the Upper Paraná River basin, to the São Francisco River and, consequently, the entire fish fauna of this river was transposed to the São Francisco River (Moreira-Filho and Buckup, 2005). Second, Blanco et al. (2010) suggested that, in the same region prior to transposition of the Piumhi River, there may have been a natural connection causing mixture of the ichthyofauna. During floods, it is likely that connections between the Grande River (Paraná hydrographic basin) and the São Francisco River through the Cururu wetland occurred, representing a natural migratory route for fish (Blanco et al., 2010).

The results of the present study suggest that the biogeographic pattern identified for the piranha species analyzed of Serrasalmus and Pygocentrus agree with the geological and hydrological events previously documented in the literature. The separation of the hydrographic basins, as well as the headwaters events and dispersion routes among the different river systems that occurred in the past, may have strongly influenced the distribution and genetic differentiation of the piranha species.

\section{Acknowledgements}

Authors are grateful to Nupelia/UEM for technical, scientific and financial support; to Furnas Centrais Elétricas; to Dr. E.K. Okada for samplings carried out in the Manso River; and to Dr. D.C. Carvalho for samplings carried out in the São Francisco River. T.S. Bignotto thanks CAPES for the scholarship grants. This study was supported by the Conselho Nacional de Desenvolvimento Científico e Tecnológico (CNPq-PELD).

\section{References}

AQUINO, A.E. and SCHAEFER, S.A., 2010. Systematics of the genus Hypoptopoma Günther, 1868 (Siluriformes, Loricariidae). Bulletin of the American Museum of Natural History, vol. 336, no. 81, pp. 1-110. http://dx.doi.org/10.1206/336.1.

BIGNOTTO, T.S., MANIGLIA, T.C., GOMES, V.N., OLIVEIRA, I.J., AGOSTINHO, C.S., PRIOLI, S.M.A.P. and PRIOLI, A.J., 2019. Genetic evidence for a species complex within the piranha Serrasalmus maculatus (Characiformes, Serrasalmidae) from three Neotropical River basins based on mitochondrial DNA sequences. 
Genetics and Molecular Biology. http://dx.doi.org/10.1590/16784685-gmb-2018-0131. PMid:31454404.

BLANCO, D.R., LUI, R.L., BERTOLLO, L.A.C., DINIZ, D. and MOREIRA-FILHO, O., 2010. Characterization of invasive fish species in a river transposition region: evolutionary chromosome studies in the genus Hoplias (Characiformes, Erytrinidae). Reviews in Fish Biology and Fisheries, vol. 20, no. 1, pp. 1-8. http://dx.doi. org/10.1007/s11160-009-9116-3.

CENTOFANTE, L., PORTO, J.I.R. and FELDBERG, E., 2002. Chromosomal polymorphism in Serrasalmus spilopleura Kner, 1858 (Characidae, Serrasalminae) from Central Amazon basin. Caryologia, vol. 55, no. 1, pp. 37-45. http://dx.doi.org/10.1080/ 00087114.2002.10589256.

CESTARI, M.M. and GALETTI JUNIOR, P.M., 1992. Chromosome studies of Serrasalmus spilopleura (Characidae, Serrasalmiane) from the Paraná-Paraguay Rivers: evolutionary and cytotaxonomic considerations. Copeia, vol. 1992, no. 1, pp. 108-112. http://dx.doi.org/10.2307/1446541.

DRUMMOND, A.J., SUCHARD, M.A., XIE, D. and RAMBAUT, A., 2012. Bayesian phylogenetics with BEAUti and the BEAST 1.7. Molecular Biology and Evolution, vol. 29, no. 8, pp. 19691973. http://dx.doi.org/10.1093/molbev/mss075. PMid:22367748.

EZARD, T., FUJISAWA, T. and BARRACLOUGH, T.G., 2009 [viewed 18 June 2019]. SPLITS: SPecies'LImits by Threshold Statistics: R package version 1.0-18/r45 [software]. Vienna: $\mathrm{R}$ Foundation for Statistical Computing. Available from: http://RForge.R-project.org/projects/splits/

FINK, W.L., 1993. Revision of the piranha genus Pygocentrus (Teleostei, Characiformes). Copeia, vol. 1993, no. 3, pp. 665-687. http://dx.doi.org/10.2307/1447228.

FINK, W.L. and ZELDITCH, M.L., 1997. Shape analysis and taxonomic status of Pygocentrus piranhas (Ostariophysi, Characiformes) from the Paraguay and Paraná River basins of South America. Copeia, vol. 1997, no. 1, pp. 179-182. http:// dx.doi.org/10.2307/1447854.

FREEMAN, B., NICO, L.G., OSENTOSKI, M., JELKS, H.L. and COLLINS, T.M., 2007. Molecular systematic of Serrasalmidae: deciphering the identities of piranha species and unraveling their evolutionary histories. Zootaxa, vol. 1484, no. 1, pp. 1-38. http:// dx.doi.org/10.11646/zootaxa.1484.1.1.

FRICKE, R., ESCHMEYER, W.N. and FONG, J.D., 2019. Catalog of fishes. San Francisco: California Academy of Sciences.

GÉRY, J., 1976. Les genres de Serrasalmidae (Pisces-Characoidei). Bulletin Zoologisch Museum Universiteit van Amsterdam, vol. 5, no. 6, pp. 47-54.

GREEN, M.R. and SAMBROOK, J., 2012. Molecular cloning: $a$ laboratory manual. 4 th ed. New York: Cold Spring Harbor, 46 p.

HALL, T.A., 2011. BioEdit: an important software for molecular biology. Green Earth Research FoundationBulletin of Biosciences, vol. 2, pp. 60-61.

HUBERT, N. and RENNO, J.-F., 2006. Historical biogeography of South American freshwater fishes. Journal of Biogeography, vol. 33, no. 8, pp. 1414-1436. http://dx.doi.org/10.1111/j.13652699.2006.01518.x.

HUBERT, N., DUPONCHELLE, F., NUÑEZ, J., GARCIADAVILA, C., PAUGY, D. and RENNO, J.F., 2007. Phylogeography of the piranha genera Serrasalmus and Pygocentrus: implications for the diversification of the Neotropical ichthyofauna. Molecular
Ecology, vol. 16, no. 10, pp. 2115-2136. http://dx.doi.org/10.1111/ j.1365-294X.2007.03267.x. PMid:17498236.

IVANOVA, N.V., ZEMLAK, T.S., HANNER, R.H. and HEBERT, P.D.N., 2007. Universal primer cocktails for fish DNA barcoding. Molecular Ecology Notes, vol. 7, no. 4, pp. 544-548. http://dx.doi. org/10.1111/j.1471-8286.2007.01748.x.

JÉGU, M., 2003. Subfamily Serrasalminae (Pacus and piranhas). In: R.E. REIS, S.O. KULLANDER and C.J. FERRARIS JUNIOR, eds. Check-List of freshwater fishes from South and Central America. Porto Alegre: EDIPUCRS, pp. 182-196.

JÚLIO JÚNIOR, H.F., TÓS, C.D., AGOSTINHO, Â.A. and PAVANELLI, C.S., 2009. A massive invasion of fish species after eliminating a natural barrier in the upper rio Paraná basin. Neotropical Ichthyology, vol. 7, no. 4, pp. 709-718. http://dx.doi. org/10.1590/S1679-62252009000400021.

KOCHER, T.D., THOMAS, W.K., MEYER, A., EDWARDS, S.V., PÄÄBO, S., VILLABLANCA, F.X. and WILSON, A.C., 1989. Dynamics of mitochondrial DNA evolution in animals: amplification and sequencing with conserved primers. Proceedings of the National Academy of Sciences of the United States of America, vol. 86, no. 16, pp. 6196-6200. http://dx.doi. org/10.1073/pnas.86.16.6196. PMid:2762322.

KUMAR, S., STECHER, G. and TAMURA, K., 2016. MEGA7: Molecular Evolutionary Genetics Analysis version 7.0 for bigger datasets. Molecular Biology and Evolution, vol. 33, no. 7, pp. 18701874. http://dx.doi.org/10.1093/molbev/msw054. PMid:27004904.

LANFEAR, R., CALCOTT, B., HO, S.Y.W. and GUINDON, S., 2012. PartitionFinder: combined selection of partitioning schemes and substitution models for phylogenetic analyses. Molecular Biology and Evolution, vol. 29, no. 6, pp. 1695-1701. http:// dx.doi.org/10.1093/molbev/mss020. PMid:22319168.

LOVEJOY, N.R. and ARAÚJO, M.L.G., 2000. Molecular systematics, biogeography, and population structure of Neotropical freshwater needlefishes of the genus Potamorrhaphis. Molecular Ecology, vol. 9, no. 3, pp. 259-268. http://dx.doi.org/10.1046/j.1365294x.2000.00845.x. PMid:10736024.

LUNDBERG, J.G., MARSHALL, L.G., GUERRERO, J., HORTON, B., MALABARBA, M.C.S.L. and WESSELINGH, F. 1998. The stage for Neotropical fish diversification: a history of tropical South American Rivers. In: L.R. MALABARBA, R.E. REIS, R.P. VARI, Z.M. LUCENA and C.A.S. LUCENA, eds. Phylogeny and classification of neotropical fishes. Porto Alegre: EDIPUCRS, pp. 13-48.

LUZ, L.A., REIS, L.L., SAMPAIO, I., BARROS, M.C. and FRAGA, E., 2015. Genetic differentiation in the populations of red piranha, Pygocentrus nattereri Kner (1860) (Characiformes: Serrasalminae), from the river basins of northeastern Brazil. Brazilian Journal of Biology $=$ Revista Brasileira de Biologia, vol. 75, no. 4, pp. 838-845. http://dx.doi.org/10.1590/15196984.00214. PMid:26675902.

MACHADO, V.N., COLLINS, R.A., OTA, R.P., ANDRADE, M.C., FARIAS, I.P. and HRBEK, T., 2018. One thousand DNA barcodes of piranhas and pacus reveal geographic structure and unrecognised diversity in the Amazon. Scientific Reports, vol. 8, no. 1, pp. 8387. http://dx.doi.org/10.1038/s41598-018-26550-x. PMid:29849152.

MACHADO-ALLISON, A., 1983. Estudios sobre la sistemática de la subfamilia Serrasalminae (Teleostei, Characidae). Parte II: discusión sobre la condición monofilética de la subfamilia. Acta Biologica Venezuelica, vol. 11, no. 4, pp. 145-195. 
MATEUSSI, N.T.B., MELO, B.F., FORESTI, F. and OLIVEIRA, C., 2019. Molecular data reveal multiple lineages in piranhas of the genus Pygocentrus (Teleostei, Characiformes). Genes, vol. 10, no. 5, pp. 371. http://dx.doi.org/10.3390/genes10050371. PMid:31096658.

MEYER, A., KOCHER, T.D., BASASIBWAKI, P. and WILSON, A.C., 1990. Monophyletic origin of Lake Victoria cichlid fishes suggested by mitochondrial DNA sequences. Nature, vol. 347, no. 6293 , pp. 550-553. http://dx.doi.org/10.1038/347550a0. PMid:2215680.

MOREIRA-FILHO, O. and BUCKUP, P.A., 2005. A poorly known case of water shed transposition between the São Francisco and upper Paraná River basins. Neotropical Ichthyology, vol. 3, no. 3, pp. 449-452. http://dx.doi.org/10.1590/S1679-62252005000300015.

NAKAYAMA, C.M., FELDBERG, E. and BERTOLLO, L.A.C., 2012. Karyotype differentiation and cytotaxonomic considerations in species of Serrasalmidae (Characiformes) from the Amazon basin. Neotropical Ichthyology, vol. 10, no. 1, pp. 53-58. http:// dx.doi.org/10.1590/S1679-62252012000100005.

NAKAYAMA, C.M., JEGÚ, M., PORTO, J.I.R. and FELDBERG, E., 2001. Karyological evidence for a cryptic species of piranha within Serrasalmus rhombeus (Characidae, Serrasalminae) in the Amazon. Copeia, vol. 2001, no. 3, pp. 866-869. http://dx.doi. org/10.1643/0045-8511(2001)001[0866:KEFACS]2.0.CO;2.

NAKAYAMA, C.M., PORTO, J.I.R. and FELDBERG, E., 2000. Ocorrência de dois citótipos em Serrasalmus spilopleura Kner, 1858 (Characiformes, Serrasalmidae) da região de confluência dos rios Negro e Solimões, Amazonas, Brasil. Acta Amazonica, vol. 30, no. 1 , pp. 149-154. http://dx.doi.org/10.1590/180943922000301154 .

NAKAYAMA, C.M., PORTO, J.I.R. and FELDBERG, E., 2002. A comparative cytogenetic study of five piranha species (Serrasalmus, Serrasalminae) from the Amazon basin. Genetica, vol. 114, no. 3, pp. 231-236. http://dx.doi.org/10.1023/A:1016275505655. PMid:12206361.

ORTÍ, G., PETRY, P., PORTO, J.I.R., JÉGU, M. and MEYER, A., 1996. Patterns of nucleotide change in mithochondrial ribossomal RNA genes and the phylogeny of piranhas. Journal of Molecular Evolution, vol. 42, no. 2, pp. 169-182. http://dx.doi.org/10.1007/ BF02198843. PMid:8919869.

ORTÍ, G., SIVASUNDAR, A., DIETZ, K. and JÉGU, M., 2008. Phylogeny of the Serrasalmidae (Characiformes) based on mitochondrial DNA sequences. Genetics and Molecular Biology, vol. 31, no. 1, pp. 343-351. http://dx.doi.org/10.1590/ S1415-47572008000200030.

PUILLANDRE, N., LAMBERT, A., BROUILLET, S. and ACHAZ, G., 2012. ABGD, Automatic Barcode Gap Discovery for primary species delimitation. Molecular Ecology, vol. 21, no. 8, pp. 1864-1877. http://dx.doi.org/10.1111/j.1365-294X.2011.05239.x. PMid:21883587.

RAMBAUT, A., 2010 [viewed 22 January 2019]. FigTree v1.3.1 [software]. Edinburgh: Institute of Evolutionary Biology, University of Edinburgh. Available from: http://tree.bio.ed.ac. uk/software/figtree/

RAMBAUT, A., SUCHARD, M.A., XIE, D. and DRUMMOND, A.J., 2014 [viewed 10 September 2017]. Tracer $v 1.6$ [software]. Available from: http://tree.bio.ed.ac.uk/software/tracer/

RSTUDIO TEAM, 2016 [viewed 18 June 2019]. RStudio: integrated development for $R$ [software]. Boston: RStudio. Available from: http://www.rstudio.com/

SIEVERS, F., WILM, A., DINEEN, D.G., GIBSON, T.J., KARPLUS, K., LI, W., LOPEZ, R., MCWILLIAM, H., REMMERT, M., SÖDING, J., THOMPSON, J.D. and HIGGINS, D.G., 2011. Fast, scalable generation of high-quality protein multiple sequence alignments using Clustal Omega. Molecular Systems Biology, vol. 7, no. 1, pp. 539. http://dx.doi.org/10.1038/ msb.2011.75. PMid:21988835.

SILVESTRO, D. and MICHALAK, I., 2012. RaxmlGUI: a graphical front-end for RAxML. Organisms, Diversity \& Evolution, vol. 12, no. 4, pp. 335-337. http://dx.doi.org/10.1007/ s13127-011-0056-0.

THOMPSON,A.W., BETANCUR-R, R., LÓPEZ-FERNÁNDEZ, H. and ORTÍ, G., 2014. A time-calibrated, multi-locus phylogeny of piranhas and pacus (Characiformes: Serrasalmidae) and a comparison of species tree methods. Molecular Phylogenetics and Evolution, vol. 81, pp. 242-257. http://dx.doi.org/10.1016/j. ympev.2014.06.018. PMid:25261120.

VAN EVERY, L.R. and KRITSKY, D.C., 1992. Neotropical Monogenoidea. 18. Anacanthorus Mizelle and Price, 1965 (Dactylogyridae, Anacanthorinae) of piranha (Characoidea, Serrasalmidae) from the central Amazon, their phylogeny, and aspects of host-parasit coevolution. Journal of the Helminthological Society of Washington, vol. 59, no. 1, pp. 52-75.

WARD, R.D., ZEMLAK, T.S., INNES, B.H., LAST, P.R. and HEBERT, P.D.N., 2005. DNA barcoding Australia's fish species. Philosophical Transactions of the Royal Society of London: Series B, Biological Sciences, vol. 360, no. 1462, pp. 1847-1857. http:// dx.doi.org/10.1098/rstb.2005.1716. PMid:16214743.

ZHANG, J., KAPLI, P., PAVLIDIS, F. and STAMATAKIS, A., 2013. A general species delimitation method with applications to phylogenetic placements. Bioinformatics, vol. 29, no. 22, pp. 2869-2876. http://dx.doi.org/10.1093/bioinformatics/btt499. PMid:23990417. 


\section{Supplementary Material}

Supplementary material accompanies this paper.

Supplementary Material 1. Polymorphism of nucleotide sites in the concatenated sequences of the mitochondrial genes Cytochrome c oxidase I (1 to $550 \mathrm{bp}$ ) and Cytochrome b (551 to 1,141 bp) of piranha species of the genera Serrasalmus and Pygocentrus from the Upper Paraná (PR), Upper Paraguay (PY), São Francisco (SF) and Tocantins (TO) River basins. Letters in bold represent diagnostic nucleotides for a species and/or population.

This material is available as part of the online article from http://www.scielo.br/bjb 